\title{
FOREIGN DIRECT INVESTMENTS IN THE ROLE OF STRENGTHENING THE EXPORT COMPETITIVENESS OF THE SERBIAN ECONOMY
}

\author{
Dejan Đurić1, Jelena Ristić ${ }^{2}$ Dragana Đurić ${ }^{3}$
}

\begin{abstract}
Summary
The globalization of economic activity imposes the need for all countries to participate intensely in the current international economic cooperation and exchange processes of goods, services, labor and capital. Greater integration into international economic and trade flows is particularly important for small countries, given that the limitation of resources and insufficient domestic production impose the need for greater imports. On the other hand, import imposes a greater need for more exports so that the growing imports could be financed. Adjusting the challenges of globalization is an important task for all countries in order to accomplish basic economic goal, and that is the growth of living standards of all citizens. In this sense, in this paper, special attention is paid to the state of foreign trade and the analysis of the effects of FDI on export competitiveness and increase exports of the national economy, as one of the most important conditions of economic progress in the future. The main objective of this paper is to highlight the importance of the impact of foreign direct investments to strengthen the export activities of the Serbian economy, and the importance of intensification of export activity and qualitative changes in the structure of domestic exports.
\end{abstract}

Key words: globalization, exports, foreign direct investments, economic growth.

JEL: $F 10, F 21,019, Q 17$

\section{Introduction}

Republic of Serbia must constantly and rapidly increase its exports to achieve continuous high tares of economic growth and a constant increase in gross domestic product and the

1 Dejan Đurić Ph.D., Full Professor, Business School of Professional studies Novi Sad, Vladimira Perica Valtera street no. 4, 21000 Novi Sad, Serbia, Phone: +381 6380574 20, E-mail: ddjuric971@gmail.com

2 Jelena Ristić Ph.D., FullProfessor, Business School of Professional studies Blace, Kralja Petra I street no. 70, 18420 Blace, Serbia, Phone: +381 63404 202, E-mail: jelenazristic@yahoo.com

3 Dragana Đurić Ph.D., Professor, Business School of Professional studies Blace, Kralja Petra I street no. 70, 18420 Blace, Serbia, Phone: +381 6580574 20, E-mail: djdragana@ikomline.net

EP 2016 (63) 2 (531-546) 
standard of living, exports. The increase in export revenue is an important condition for servicing the fiscal deficit and high levels of external debt and it provides financing for the import of equipment and technology, which also implies a prerequisite for economic development in the coming years (Đurić et al., 2011). The projected dynamic growth of external debt shows that an increasing share of gross domestic product for regular servicing of debt obligations of domestic product should be allocated in the future. With the increase in repayment of debt falling due in the coming years, the pressure on foreign exchange reserves will grow, so it is necessary to insist on increased exports as the best way of financing the deficit of the trade balance. In order to achieve this, it is necessary to work towards more intensive attracting of foreign direct investments and achieving qualitative changes in the structure of domestic exports and to adapt global demand for imports. Bearing in mind the fact that foreign direct investments is an important means of strengthening export activity and further development of the Serbian economy, the strategy of influx of international capital movements must become the backbone of its future economic and development policies.

\section{Methodology}

Theoretical elaboration and the goals have influence the authors of this paper to use the descriptive, comparative-historical and analytical-synthetical methodology, whereby an attempt was made to consider and understand the problem. Moreover, the analysis of the content of the adopted documents and the results of previous research was used. The research was performed during the period from 2000 to 2014. The basic data sources are represented by the statistics of the external trade and foreign direct investments, materials of the Ministry of Finances of the Republic of Serbia, Chamber of Commerce of Serbia, the World Bank and other relevant sources.

\section{The need to strengthen the export activities of the national economy}

The Republic of Serbia, as a relatively small country with underdeveloped infrastructure, unfavorable economic structure and modest development resources, must strive to build an export-oriented economy, with developed tradable goods sector (industry and agriculture). In this country, there is a need for an increase in exports due to the following reasons:

- The limitations of the domestic market cannot provide the economies of scale, and thus one of the most important conditions for strengthening the competitive position of domestic companies on the world market;

- Lack of basic production inputs and the necessity of meeting the needs of all citizens, through the purchase of goods and services, will inevitably lead to the growth of imports, which increases the need for greater exports to the foreign trade sector held in balance. A small country cannot provide a wide enough range of goods and must therefore import and in order to pay for imports must provide the required level of exports. 
Given the importance of exports to Republic of Serbia, it is clear that without its growth it cannot achieve its main economic goals. In this sense, the main task of economic policy in the coming period is to increase exports in order to:

- Increase production and hence employment and living standard;

- Ensure macroeconomic stability by reducing the sensitivity of economic growth in the size of capital inflows and

- Allow regular servicing of external debt (Ministry of Finance of the Republic of Serbia, 2011).

The basic measure of the competitiveness of modern economies is the ability of companies, industries and sectors of the economy to lower operating costs and development time and achieve economic competitiveness and competitiveness on the basis of price, as well as the ability of companies, industries and sectors of the economy to improve performances of products and services, above all, quality, functions and after-sales service. Based on this criteria, the largest part of the economy of Serbia lacks sufficient ability to reduce costs and improve product quality, and consequently it does not reach the necessary economic and technological competitiveness in domestic and foreign markets (Đurić, 2007). In this regard, the foreign investors can significantly contribute a stimulating economic environment by addressing problem of low competitiveness of local exports, together with local entrepreneurs and investors. On these grounds, the production, export and technological performance of the Serbian economy could be improved along with the raise of the level of its international competitiveness.

Special importance for reducing the foreign trade imbalance in the coming period will be the inflow of foreign direct investments (FDI), mainly Greenfield investment in export-oriented sectors of the economy in which they need to increase productivity, exports and foreign exchange inflows. These sectors boost export offer and reduce import demand and thereby improve the balance of payments position of the country and lead to financing of the current account deficit, without increase of government borrowing.

\section{Developments in the foreign trade sector of the national economy after 2000}

The long isolation of our economy and international economic relations during the nineties of the 20th century, led to a negative economic consequences in the field of foreign trade operations. As a result of wars, economic sanctions, loss of markets and the unstable political environment, in this period there was a dramatic fall in the level of overall economic trends, the reduction of domestic accumulation and a large decline in the level of export activity.

One of the indicators of the relative importance of foreign trade to the domestic economy is the one that points to the share of exports and imports in gross domestic product (GDP) - the coefficient of foreign trade. In the last decade of the 20th century, 
the export of the Federal Republic of Yugoslavia (FRY) experienced a lot of pitching, which was directly reflected in the reduction of its share in GDP (export coefficient). The value of this ratio fell from $23 \%$ in 1990 to only $13.2 \%$ in $2000 .{ }^{4}$ The scale of the decline in export flows in the reporting period can be seen on the basis that the share of merchandise exports FRY in world merchandise exports in 1990. It amounted up to $0.17 \%$. After that the fall of this share followed and it was reduced to $0.03 \%$ in 2000 (WTO, 2003).

Unlike the successful countries in transition, the situation in the export sector of the Serbian economy in the reporting period was far worse. Besides the decline in the value of merchandise exports, at the same time there was a serious deterioration of its qualitative performance, which, along with other restrictions, also led to a decrease in our trade with foreign countries. The disadvantage of the structure of domestic exports was reflected in the fact that in the period from 1990 to 2000, the share of primary products in world merchandise exports decreased from $26.5 \%$ to $20.1 \%$, while our exports increased from $23.5 \%$ to as much as $50 \%$ (World Bank, 2001). Agricultural production and extractive activities represented a pillar of Serbian foreign trade, and the share of finished products in the structure of total exports showed a negative trend. Domestic exports did not follow the flows of world import demands and it was based on traditional export structure. All this resulted in a summary result of falling levels of exports and expansion of the trade deficit, which was a "trademark" of the Yugoslav economy in that period (Kovačević, 2005).

After 2000 there was a re-inclusion of our country in the international economic environment. This led to a revival of foreign trade activities. The long isolation from the world market and the inability to come up with necessary products caused a strong need for the dynamic import of goods and services, which caused an increase in the trade deficit and current account deficit.

Table 1. Merchandise trade balance of the Republic of Serbia for the period from 2001 to 2014 (mil. USD)

\begin{tabular}{|c|r|r|r|c|c|}
\hline Year & Export & Import & Balance & $\begin{array}{c}\text { Coverage of } \\
\text { imports by exports } \\
(\%)\end{array}$ & $\begin{array}{c}\text { Foreign trade } \\
\text { deficit as \% GDP }\end{array}$ \\
\hline 2001 & 1720 & 4260 & -2540 & 40 & 21 \\
\hline 2002 & 2074 & 5614 & -3540 & 36 & 22 \\
\hline 2003 & 2756 & 7477 & -4721 & 36 & 24 \\
\hline 2004 & 2523 & 10755 & -7232 & 32 & 30 \\
\hline 2005 & 4480 & 10461 & -5981 & 41 & 24 \\
\hline 2006 & 6431 & 13174 & -6743 & 48 & 23 \\
\hline 2007 & 8823 & 19165 & -10342 & 46 & 25 \\
\hline 2008 & 10974 & 24332 & -13358 & 45 & 25 \\
\hline 2009 & 8345 & 15808 & -7463 & 52 & 19 \\
\hline 2010 & 9794 & 16471 & -6677 & 59 & 17 \\
\hline
\end{tabular}

4 Exports data and GDP of FRJ are from Statistical Office of Serbia, corresponding year. 


\begin{tabular}{|l|l|l|l|l|l|}
\hline 2011 & 11780 & 19862 & -8082 & 59 & 17 \\
\hline 2012 & 11229 & 18928 & -7699 & 59 & 19 \\
\hline 2013 & 14612 & 20553 & -5941 & 71 & 13 \\
\hline 2014 & 14845 & 20650 & -5805 & 71 & 13 \\
\hline
\end{tabular}

Source: http://webrsz.stat.gov.rs/WebSite/

On the basis of information on developments in the foreign trade sector of the Serbian economy after 2000, we can conclude that in the years after 2000 a basic feature of the trade balance of our country was the existence of the high level of trade deficit. It was held at a relatively high level of above $20 \%$ of GDP, with that in 2004 it amounted up to $30 \%$ of GDP. In 2005 there was a reduction of the share of trade deficit in GDP of Serbia (30.4\% of GDP in 2004 to $23.8 \%$ in 2005), as a result of the growth of slowing export and import activities in that year. The high share of foreign trade deficit in gross domestic product was also observed in $2006(23 \%)$ and $2007(25 \%)$ and 2008 (25\%). In 2008 there was a record of high deficit of over 13 billion USD. The main reason for such a high deficit in this period was the growth of private and public consumption (real growth in public sector wages and excessive public spending) and the insufficient supply of some essential products from domestic production which would be competitive imported products.

Based on the indicators in the table above we can see that in 2009 the volume of foreign trade was reduced and foreign trade deficit (significant reduction in imports than exports). Foreign trade in 2009 was significantly decreased compared to the previous year. The fall in world prices of primary products, the decline in world demand as a result of the global financial crisis and the real depreciation of the dinar influenced the values of exports and imports in 2009 which were significantly below the levels in 2008. Export of goods, expressed in dollars was reduced from 10.9 billion USD to 8.3 billion USD. At the same time imports decreased from 24.3 billion USD to 15.8 billion USD. The larger decline in imports than in exports resulted in a reduction of the trade deficit from 13.3 billion USD to 7.5 billion USD and higher coverage of imports by exports $(52 \%)$.

In 2010, speaking at an international level, exports and imports of goods increased (values are expressed in US dollars), while the coverage of imports by exports was $59 \%$. At the end of 2010, the foreign trade deficit amounted 6.6 billion USD. The growth in merchandise exports this year, was the result of a recovery section, which in previous years were the pillars of exports, and which were most affected by the crisis, and they were the segments of iron and steel and non-ferrous metals. Exports of these two segments increased compared to 2009 by $56.6 \%$ and $66.8 \%$, respectively.

Export of goods in 2011 increased from 9.8 billion USD to 11.8 billion USD. Imports of goods also increased, from 16.5 billion USD to 19.9 billion USD, while the trade deficit was higher by about 1.4 billion USD compared to the previous year and amounted 8.1 billion USD. Significant growth in exports is the result of an increase in exports of metal ores, base metals, agricultural products and the manufacture of rubber and 
plastic, as a result of the growth in export demands. The coverage of imports by exports was $59 \%$. The level of trade with foreign countries in 2012 remained at about the same level as in the previous year, along with the certain reduction in the trade deficit.

Merchandise exports in 2013 were higher than in the year of 2012 by $30.1 \%$, while imports rose by $8.5 \%$. The exchange of goods with foreign countries in 2013 was a deficit in the amount of 5.9 billion USD, representing a decrease of as much as $23 \%$ compared to the year 2012. The coverage of imports by exports in this year was $71 \%$, and it was greater than the coverage in 2012, when it amounted to 59\% (www.pks.rs).

The total foreign trade of the Republic of Serbia in 2014 amounted to about 35 billion USD, which represented the growth of $0.9 \%$ compared to the previous year. Merchandise exports reached a value of 14.8 billion USD; an increase of $1.6 \%$ compared to the previous year, and imported goods worth 20.6 billion USD, which was $0.5 \%$ more than in 2013. In 2014, there was a negative balance of trade in the amount of 5.8 billion USD, which was $2.2 \%$ less than in the previous year, while the export-import ratio was $71.9 \%$, which was slightly more than in the corresponding period of coverage in 2013 when it amounted to $71.1 \%$.

Such movements of foreign trade flows in recent years, where the share of merchandise exports has almost continuously been increasing, which, along with the stabilization of the share of merchandise imports, have led to a substantial decline in participation of foreign trade deficit. It should be noted that the positive trend, even in conditions of stagnation or decline in GDP, and even stagnation of exports, after 2008 there has been no significant increase in the share of foreign trade deficit in GDP. However, this does not mean that there has been a strong improvement of export activities in our country. That can be concluded on the basis that the export of Serbia in relation to GDP is still considerably lower than in similar countries of Central Europe. While Serbia's export of goods and services in 2014 amounted to 44\% of GDP, the share of exports in GDP in countries of similar size (Bulgaria, the Czech Republic and Hungary), in the same year was about $80 \%$. Starting from the level of external debt of the country and the need to import raw materials and semi-final goods for domestic production, export ratio would have to reach a value of above 50\% GDP (Ministry of Finance of the Republic of Serbia). Accordingly Serbia has great space for export growth and reducing the trade deficit on this basis. In addition, export growth is a key drive of sustainable growth of the Serbian economy in the coming years, and would double-digit growth rates of exports accounted signal that Serbia is on a sustainable growth path (Quarterly monitor, 2015).

\section{The export structure as the source of the problem of domestic exports}

An assessment of the strong progress of Serbia in the field of export performances could be also acquired on the basis of changes in the export structure of the domestic economy in recent years. However, this conclusion is only partially standing. The rapid improvement of the export structure in the last two years, resulting in the start of production of Fiat (FAS), has, due to the very low volume of total exports, dramatically changed the export structure of the domestic economy. In any case, only the strong 
potential growth in domestic exports which would in per capita terms or as a share of GDP be near to the one of the countries of the region, could mean that we are on the road of full recovery of domestic exports. For if the structure would still remain similar to the one we have today, we could talk about a strong qualitative shift. Thus, with exports in per capita term which is several times lower than in most countries in the region, export picture remains bleak. In fact, exports in 2013 amounted to only 14.6 billion USD and two times lower than the Bulgarian, just exceeded the Croatian, and 7.4 times less than Hungarian and 10.2 times lower than the Czech. Serbia's exports per capita of 1.530 EUR in 2013 is one of the lowest of all the countries in transition (e.g. Czech exports amounted to 10.740 EUR pc; 8.254 EUR pc Hungary, Slovakia 14.627 EUR pc. This leads us to the conclusion that growth of domestic trade since 2000 has been impressive, but it was achieved with a very low base, so that Serbia has, in absolute figures a very low export (Nikolić, 2014).

The main structural problems of domestic exports are:

- Export structure is based on domination of reproduction i.e. production of low level of processing,

- Low level of production concentration, despite the relatively small value of total exports,

- Lack of competitiveness of the export offer in terms of products (design and product development, technical standards, durability and appearance, presentation) and in terms of price (the price of raw materials, cost of financing, taxes and transportation)

- Export activities of several firms determine the overall dynamics of exports (Fiat Serbia, Smederevo steel plant, rolling mill copper and aluminum, Gorenje, Tigar ...) due to the low value of exports,

- Production and export of the food industry are largely influenced by meteorological conditions (genus farming),

- There is a significant correlation between exports and imports, even the biggest exporters and the largest importers. ${ }^{5}$

So there are many problems which limit the powerful boosting export activities of Serbian economy. The first highlight in an adequate structure of the domestic economy, i.e. unfavorable export structure, cannot provide sufficient competitiveness in the international market. The export structure of our country is still dominated by products for reproduction i.e. products with a low degree of processing, and the structural changes in the real sector basically lead to an assumption for raising export competitiveness to a higher level. During the period from 2000 to 2014 a moderate structural improvement

5 In a situation where the largest exporters are at the same time the largest importers, it is difficult to reduce a country's foreign trade deficit; therefore, one of the possible solutions for reducing this deficit may be import substitution by developing a supplier network from the domestic market.

EP 2016 (63) 2 (531-546) 
of domestic exports of goods was recorded, which can be seen through the increase in the share of final products. The technological structure and factor intensity of goods exports have improved, but these changes have not in a critical extent improved the structure of domestic exports and thereby created the conditions for its strong longterm growth. The level of quality of Serbian goods exports still significantly lags behind other countries in the EU, and to a lesser extent, the economies of Central Europe.

Geographic structure of the domestic economy foreign trades points to the fact that most of the national exports are directed to the EU market and CEFTA countries (over $80 \%$ ). Observed by countries, the most important foreign trade partners of Serbia are Italy, Germany, Bosnia and Herzegovina, the Russian Federation and Romania.

Export structure is not well geographically diversified - as much as $90 \%$ surplus of Republic of Serbia is realized with only three countries: Macedonia, Montenegro and Bosnia and Herzegovina. The high concentration of Serbian exports to only a few countries may have a negative impact on the further growth of exports. Therefore, one of the main tasks of foreign policy and the future development is directing the companies into new markets.

In order to achieve optimal geographic diversification of exports, the entry of companies into new markets should flow in two directions:

- In the direction of the market with high growth potential and/or large purchasing power and/or

- In the direction of markets that have been traditional partners of the former Yugoslavia.

In this sense, we can mark four key export markets for Serbia. These are: the European Union; CEFTA; Commonwealth of Independent States (CIS); Near and Middle East and North Africa (BSISA).

Previous analysis of the volume and dynamics of export and commodity export structure of the national economy, points to the conclusion that the increase in the value of exports and improving its structure must become the backbone of our development policy in the future. It is clear that Serbia needs a new development strategy that will focus on reducing unproductive public spending and raising the level of investments and exports in GDP. Such a strategy is practically unfeasible without additional foreign accumulation, i.e., without the inflow of foreign direct investments that may affect the significant increase of the commodity export potentials.

Existing export structure does not provide enough space for bigger growth of total export. Traditional export structure shows a delay of structural changes in import demand in developed countries. The sharp shift in this structure, which would fit contemporary tendencies structure of import demand, is not easy and it involves opening up the reform process in the real sector of the economy. In this regard, enhancing foreign direct investments is crucial to the realization of a new paradigm of economic growth and rising export activity (Nikolić, 2014). A special importance to reduce the foreign 
trade imbalance in the coming period will be the inflow of foreign direct investments, primarily greenfield investment in export-oriented sectors of the economy where the increase of productivity, exports and foreign exchange inflows is needed.

\section{The impact of FDI on exports of the host country}

Foreign direct investments represent the most important source of financing for the development of domestic economy (Đurić, 2006). In today's conditions, foreign direct investments (FDI) assumes a key function of the development factors, along with the trade as the main mechanism for the globalization of the world economy. Realizing foreign direct investments, economic entities deploy their production systems and other business functions on a global scale, trying to provide the best supply of raw materials, energy and labor, on the one hand, and profitable marketing of their products and services on the other (Đurić et al., 2012). Their significance can not only be seen in the inflow of the necessary funds for investments, but also in the opening of processes of partnership relations with companies from the most developed countries, which represent the development carriers in their activities (Savić, 2002). The influence of foreign direct investments on the structure and specialization of import depends on numerous factors, such as: cumulative level of foreign direct investments, the types of foreign investments (greenfield investments directly affect the rise in the level of gross investments in comparison to the acquisitions in relation to the privatization process, whereby only the change in ownership occurs), sector distribution (only investments in the sector for tradable goods can affect the change in the import structure), the technology type which companies with foreign ownerships use in production and the absorptive capacity of domestic enterprises (Boljanović, 2013).

A special significance of foreign direct investments activities is that it has that component of the investment package which relates to the provision of access to international markets for goods and capital and the expansion of exports of industrial and other products. In addition to bringing the capital to the modern technological knowledge, foreign direct investments also allow easier access to international trade and integration into the global distribution network of global organizations (Đurić, 2003). In this regard, some of the main effects of FDI on the export competitiveness of the domestic economy are as follows (UNCTAD, 2000):

- Ensuring access to international markets. Export promotion includes not only competitive products, but also the necessity of expertise and knowledge in the field of marketing and international business. The biggest benefits of FDI can be brought right on in this area, especially when it comes to markets where widespread distribution network and creation of trade marks (brand names) play an important role in product placement. The trade of products with high technological value (which generally takes place between global organizations and their branches - the so - called. Intercompany trade), and the inclusion in the network of global organizations can be of a crucial importance for increasing exports. 
- Building local connections. In a situation where a global organization provide inputs for their production in local markets, FDI in the context of export-oriented sectors indirectly links domestic suppliers with foreign markets. Such domestic companies can eventually become able to act independently in international markets, too.

- Creating static competitive advantages. The inflow of foreign direct investments, the host country may provide the missing resources such as capital goods, knowledge, technology, etc., which are necessary for the effective use of existing comparative advantages (natural resources, cheap labor, etc.).

- Creating dynamic competitive advantages. In countries with good educational base, global organizations can contribute to the creation of dynamic benefits of the competing, bringing new knowledge and technology. This was the case with dynamic sectors, such as electronic, material handling in some countries in Southeast Asia. SDI enabled the development of new export-oriented industries, especially electronic, by providing preferential access to export markets within the system of global organizations, or through links with them. Thus, in the electronic industry, the American global organization established branches in Asia, as part of its integrated network of production and trade. As a result of the intensive export activities of US subsidiaries, some of the countries of the region (Singapore, Malaysia, Taiwan, South Korea, etc.) have been integrated into the international division of labor in the electronic industry and specialized in the production for the world market. These countries, which in 70's of the 20th century were the location for installation of the product of Japanese and American global organizations today are involved in all stages of production in the semiconductor industry, electronics, computers, and are significant actors in the global trade. Malaysia has become one of the world's largest exporter and manufacturer of electronics and semiconductors, and South Korea, Taiwan and Singapore's largest exporters of semiconductors and other electronic components from developing countries and among the leaders in the world, relying in large part on technology, organizational skills and global network marketing organizations from developed countries.

The contribution of foreign direct investments (FDI) activity strengthening export performance of the host countries of this form of international capital movements is particularly important for developing countries and countries in transition. Foreign branches in these countries were mostly more export - oriented in relation to domestic firms, and their propensity to export increased proportionally length of time performing economic activity on a foreign destination, which has maintained a positive role in the growth of the participation of the aforementioned groups of countries in total world exports. By bringing new production activities based on modern technology and knowledge, and linking local production to global corporate systems, foreign companies have largely been holders of creating new foreign trade flows.

In the context of the positive impact of FDI on export activity and changes in the export structure, an example of some of the former socialist countries (Poland, Czech Republic, Slovakia, Slovenia and Hungary), which joined the European Union in 2004. 
can be cited. These countries have in the early nineties courageously embarked on reforms, achieved a drastic change in the trade structure and practically got a new role in the international division of labour. From traditional exporters of raw materials and products of lower processing phase, during the nineties the observed countries have increased manifold during of export products of higher stages of finalization. Relatively rapid liberalization and a significant inflow of foreign capital, the first through privatization, and later thanks to a favorable institutional infrastructure, have been crucial for this shift. Their exports to the EU in the period $1993-2001$ increased from 29.712 million to 91.769 million USD, respectively, for over three times (Adam et al., 2003). As the evidence of improving export situation of these countries, we can mention the fact that exports of Czechoslovakia in 1990 amounted to 10.7 billion USD to the total exports of the Czech Republic and Slovakia in 2001 which reached 46 billion USD (Kovačević, 2005).

Empirical data show that foreign direct investments in these countries is mainly exportoriented. In Hungary, for example, in $199870 \%$ of the sales of the industrial sector were conducted by the subsidiaries, which in the same year realized the $86 \%$ of the exports of the industrial sector of the country. Companies with foreign capital achieved in the same year, about $53 \%$ of Polish exports to the industrial sector and $47 \%$ of exports of this sector in the economy of Czech Republic (OECD, 2000). Dynamic growth of foreign trade of the observed countries in transition was accompanied by significant changes in the structure of their exports. Thus, for example, in 2000 in Poland the dominance of machinery and transport equipment in the total structure of its exports (34.2\%) was recorded, while in 1993 the share of this equipment was only $20.1 \%$ (UNIDO, 2001).

\section{Volume and dynamics of foreign direct investments}

The change of political attitude of the international community towards our country and its reintegration into the global integration process, led in the early 21 st century, to a significant increase of interest of foreign investors in the domestic economy. All this has contributed to the investment climate in our country as a lot more attractive, which has led to serious attracting foreign direct investments in our economy.

The total amount of FDI in 2001 amounted to 184 mil. EUR, which is 2,5 times more compared to the foreign capital invested in 2000. In terms of sectorial structure and activities of the foreign capital invested in 2001 in a variety of activities were represented, with a dominant share of trade and services in the field of traffic (more than half of the total number of registered contracts related to this area). In this year, significant amounts of foreign investments were invested in the banking sector. In 2002 the inflow of foreign direct investments in the Serbian economy amounted to 500 mil USD, and in total foreign investments hand in cash as a result of taking significant privatization ventures dominated. In this sense, tender sales of shares of cement plants particularly stand out. 
Table 2. Foreign direct investments net, annual and cumulative, in million EUR

\begin{tabular}{|r|r|r|r|r|r|r|}
\hline \multirow{2}{*}{ Year } & \multicolumn{2}{|c|}{ in mil EUR } & \multicolumn{2}{c|}{ \% as GDP } & \multicolumn{2}{c|}{ Per capita in EUR } \\
\cline { 2 - 7 } & Per year & Cumulative & \multicolumn{1}{c|}{ Per year } & cumulative & Per year & Cumulative \\
\hline 2001 & 184 & 1.098 & 1,4 & 8,6 & 25 & 146 \\
\hline 2002 & 500 & 1.598 & 3,1 & 10,0 & 67 & 213 \\
\hline 2003 & 1.194 & 2.792 & 6,9 & 16,1 & 160 & 373 \\
\hline 2004 & 774 & 3.566 & 4,1 & 18,7 & 104 & 478 \\
\hline 2005 & 1.250 & 4.816 & 6,2 & 23,7 & 168 & 647 \\
\hline 2006 & 3.323 & 8.139 & 14,3 & 34,9 & 448 & 1.098 \\
\hline 2007 & 1.821 & 9.960 & 6,4 & 35,0 & 247 & 1.349 \\
\hline 2008 & 1.824 & 11.784 & 5,6 & 36,3 & 248 & 1.603 \\
\hline 2009 & 1.372 & 13.156 & 4,8 & 45,5 & 187 & 1.797 \\
\hline
\end{tabular}

Source: National Bank of Serbia, Republican Bureau of Statistics

The inflow of foreign direct investments in 2003 reached a value of 1.194 million. EUR, mainly thanks to the sale of companies from the tobacco industry, while in 2004 there was a reduction in foreign investment, as a result of a slowdown of the privatization process. In 2005 there was a revival of SDI activities and, above all, in the banking sector, and in 2006 it came to selling of telecommunications company "Mobi 63" for 1,5 billion EUR and the pharmaceutical companies "Hemofarm" to 485 mil EUR, which, along with other investments, led to the total FDI inflow in the amount of over EUR 3 billion. In 2007 and 2008 there was the annual FDI inflow of around EUR 1.8 billion.

At the end of the first decade of the 21 st century the global economy was struck by the economic and financial crisis. The economic crisis in the world was first reflected in the flows of foreign direct investments. The inflow of foreign direct investments in 2009 dropped significantly in Serbia and other transition countries of Southeast Europe. The impact of the crisis on FDI reduction of inflows was followed by other factors, such as exhausted possibilities of privatization and structural weaknesses of the economy. Serbia in 2009 managed to attract 1.4 billion EUR net of foreign direct investments, which was 452 million EUR less than in 2008 (Ministry of Finance of the Republic of Serbia, 2011).

In 2010 the downward trend in FDI continued, while inflows of foreign direct investments in Serbia in 2011 established the tendency of growth. A record amount of net FDI in 2011 was achieved in July, when it was accounted at 419.6 mil. EUR, thanks to the incoming payment of Delhaize Group for the purchase of shares of Delta Maxi (Ministry of Finance of the Republic of Serbia, 2011). In 2012, the total value of FDI inflow was one fifth lower than in 2011, and in 2013 the FDI inflow was lower than in the 2012.

In the period from 2001 to 2013, cumulative FDI inflows to Serbia amounted to 22.8 billion USD, and according to this indicator, Serbia was at $67^{\text {th }}$ position in the world. Of the countries in the region in the reporting period, the greater inflows of investments were in: Romania (70.3 billion USD), Hungary (68.5), Bulgaria (51.8) and 
Greece (29.8). Smaller inflow than Serbia in the neighborhood countries had: Albania (8.2), Montenegro (7.1), Bosnia and Herzegovina (7), and Macedonia (4.3) (www. makroekonomija.org; Biznis i finansije, 2014).

Foreign direct investments after 2000 was largely directed towards the areas of financial intermediation, wholesale and retail, manufacturing and real estate. The structure of investment indicates that the dominant capital inflow was motivated by providing quality services to the domestic sector. A small number of investments were directed to the industrial sector, which lead to an increase in exports and competitiveness (Mitra, 2011).

Realization of foreign direct investments in Serbia since 2000, largely took place through the purchase of companies in the privatization process, while the so-called Greenfield investments were not sufficiently represented. The FDI inflow was, for the most part, motivated by buying local monopoly or oligopoly in finance, manufacturing cement, cigarettes, energy and retail. Green field investments (investments in the construction of a new industrial capacity) did not represent the dominant form of foreign capital into our economy, and examples from the region indicate that a significant driver of economic development and the intensification of export activities were just green field investments. Therefore, this type of inflow of foreign investments must become the backbone of our strategy of attracting foreign capital in the future.

It is obvious that after 2000 there was a significant increase in foreign direct investments in our country. However, although there was a significantly larger and encouraging inflow of foreign capital, its extent was insufficient from the standpoint of the development needs of the national economy.

Bearing in mind the fact that FDI is an important means of strengthening export activity and further development of the Serbian economy, the inflow of foreign capital strategy must become the backbone of its economic and development policies (Đurić et al., 2010). To this end, it is essential to define priority areas and branches for foreign investments, and to determine the most desirable form of this inflow. It is necessary for The National Strategy for the inflow of foreign capital to identify the type of foreign investments needed and economic areas to be developed. In order to attract FDI in a more successful way, it is necessary to quickly eliminate existing barriers and constraints and to take measures in the direction of: the elimination of economic and political risks, creating a predictable business conditions, rapid implementation of the initiated economic changes, the further involvement of countries in the international financial and political organizations and others. Otherwise, foreign investors would continue the cautious treatment of Serbia as unattractive and a high-risk area for investment, which for our exports and the overall economy could have extremely negative consequences.

\section{Conclusion}

Analysis of the scale and dynamics of export and commodity export structure of the national economy, points us to the conclusion that the increase in the value of exports and improving its structure must become the backbone of our development policy in 
the future. It is clear that the country needs new development strategy, which will be based on increasing the investments and exports share in the gross domestic product. Such a strategy is practically unfeasible without additional foreign accumulation, i.e., without the inflow of foreign direct investments that may influence the significant increase of the exports potentials. This means that the foreign investors, together with local entrepreneurs and investors can significantly contribute to solving the problem of low competitiveness of local exports in a stimulating economic environment. On these ground the export and technological performances of the Serbian economy would improve and the level of its international competitiveness would rise. In this sense, the intensification of foreign direct investments is crucial to the realization of a new paradigm of economic growth and the growth of export activities.

\section{Bibliography}

1. Adam, A., Kosma, T. S. and McHugh, J. (2003): Trade Liberalization Strategies: What Could Southeastern Europe Learn from CEFTA and BFTA, IMF Working Paper WP/03/239, IMF, Washington, pp. 19.

2. Boljanović, S. (2013): Komparativna analiza uticaja stranih direktnih investicija na strukturu i specijalizaciju srpskog i mađarskog izvoza, Ekonomske teme 51(1):120, Ekonomski fakultet, Niš, Srbija, pp. 37.

3. Đurić, D. (2007): Jačanje i unapređenje izvoznih aktivnosti kao najvažniji cilj ekonomske politike u 2007. godini, Konferencija - Izazovi ekonomske politike Srbije u 2007. godini, Naučno društvo ekonomista sa AEN i Ekonomski fakultet u Beogradu, Beograd, Srbija, pp. 273.

4. Đurić, D., (2006): Reintegracija srpske privrede $i$ rezultati tranzicije u svetlu privlačenja stranih direktnih investicija, Ekonomski anali, Tematski broj, april 2006, godina LI, Ekonomski fakultet, Beograd, Srbija, pp. 280.

5. Đurić, D. (2003): Ekonomsko finansijski odnosi sa inostranstvom - politika $i$ praktične mere unapređenja izvoza, Ekonomski anali, Tematski broj, Beograd, Srbija, pp. 189.

6. Đurić, D., Đurić, D., Maksimović, D. (2010): Strane direktne investicione aktivnosti u Srbiji - stanje i perspektive, Institucionalne promene kao determinanta privrednog razvoja Srbije - monografija, Univerzitet u Kragujevcu, Ekonomski fakultet, Srbija, pp. 153.

7. Đurić, D., Đorđević, M., Tomić, R. (2012): Nacionalna ekonomija, Alfa-Graf NS, Novi Sad, Srbija.

8. Đurić, D., Živkov, D., Kolar. S. (2011): Problemi fiskalnih neravnoteža i mogući rizici koji proizilaze u postkriznom period, Ekonomika poljoprivrede, Vol. 58, No. 2, IEP, Beograd, Srbija, pp. 299.

9. Kovačević, R. (2005): Ekonomski odnosi Srbije sa inostranstvom, Centar za izdavačku delatnost Eekonomskog fakulteta u Beogradu, Beograd, Srbija, pp. 250272. 
10.Quarterly monitor: (2015), No. 40.

11. Ministry of Finance of the Republic of Serbia (2011): The strategy of increasing exports to the Republic of Serbia for the period 2008 to 2011, Belgrade, Serbia, pp. 1.

12. Ministry of Finance of the Republic of Serbia (2011): Development Report Serbia 2010, Belgrade, Serbia, pp. 19-141.

13. Mitra, P. (2011): Capital Flows to EU New Member States: Does Sector Destination Matter? (IMF Working Paper WP/11/167), Washington, D.C.: International Monetary Fund, pp. 5.

14. Nikolić, G. (2014): Strukturno unapređenje domaćeg robnog izvoza, Časopis Finansije, Ministarstvo finansija Republike Srbije, pp. 15-21.

15.OECD, (2000): Recent FDI trends, Policies and Challenges in SEE Countries in Comparison with Other Regions in Transition, The Vienna for International Economic Studies, Vienna.

16.OECD and CEFTA (2010): Trade Integration, Industry Concentration and FDI Inflows; The Experience in Central and South Eastern Europe, Paris.

17.Savić, Lj. (2002): Kako u uslovima privatizacije u Jugoslaviji povećati priliv stranih direktnih investicija“, Ekonomske teme, Vol. 40, No. 1-2, Ekonomski fakultet, Niš, Srbija, pp. 203.

18.UNIDO, (2001): How to DO Business in Poland, Warsaw, pp. 64.

19.UNCTAD, (2000): World Investment Report 2000, New York and Geneva, pp. 190.

20. World Economic Forum (2011): Global competitiveness report 2011-2012, Geneva.

21.WTO, (2003): World Trade Report 2003, pp. 8. 


\title{
STRANE DIREKTNE INVESTICIJE U FUNKCIJI JAČANJA IZVOZNE KONKURENTNOSTI PRIVREDE SRBIJE
}

\author{
Dejan Đurić, ${ }^{6}$ Jelena Ristić, ${ }^{7}$ Dragana Đuric ${ }^{8}$
}

\begin{abstract}
Rezime
Globalizacija ekonomskih aktivnosti nameće potrebu svim zemljama da se intenzivno uključuju u tokove međunarodne ekonomske saradnje i procese razmene roba, usluga, rada i kapitala. Veća integrisanost u međunarodne ekonomske i trgovinske tokove naročito je značajna za male zemlje, sobzirom na to da limitiranost resursa i nedovoljna domaća proizvodnja nameću potrebu za većim uvozom. Sa druge strane, veći uvoz nameće potrebu za većim izvozom, da bi se rastući uvoz mogao finansirati. Prilagođavanje izazovima globalizacije važan je zadatak svih država, kako bi se mogao ostvariti osnovni ekonomski cilj, a to je rast životnog standarda svih građana. U tom smislu, u okviru ovog rada, posebna pažnja se posvećuje stanju spoljnotrgovinske razmene $i$ analizi efekata stranih direktnih investicija na izvoznu konkurentnost i povećanje izvoza nacionalne ekonomije, kao jednom od najbitnijih uslova ekonomskog napredovanja u budućnosti. Osnovni cilj rada je da se ukaže na značaj uticaja stranih direktnih investicija na jačanje izvoznih aktivnosti privrede Srbije, kao i na važnost dinamiziranja izvoznih aktivnosti i kvalitativnih promena strukture domaćeg izvoza. Teorijska elaboracija i postavljeni zadaci opredelili su nas da u radu koristimo deskriptivnu, komparativno-istorijsku i analitičko-sintetičku metodu, kao i analizu sadržaja.
\end{abstract}

Ključne reči: globalizacija, izvoz, strane direktne investicije, ekonomski rast.

6 Redovni profesor, dr Dejan Đurić, Visoka poslovna škola strukovnih studija Novi Sad, Ulica Vladimira Perića Valtera br. 4, 21000 Novi Sad, Srbija, Telefon: +381 6380574 20, E-mail: ddjuric971@gmail.com

7 Redovni profesor, dr Jelena Ristić, Visoka poslovna škola strukovnih studija Blace, Ulica Kralja Petra I br. 70, 18420 Blace, Srbija, Telefon: +381 63404 202, E-mail: jelenazristic@yahoo.com

8 Redovni profesor, dr Dragana Đurić, Visoka poslovna škola strukovnih studija Blace, Ulica Kralja Petra I br. 70, 18420 Blace, Srbija, Telefon: +381 6580574 20, E-mail: djdragana@,ikomline.net 